\title{
Smart Technologies in Housing and Communal Services
}

\author{
Irina G. Sergeeva \\ Faculty of Technological Management and Innovations \\ ITMO University \\ St. Petersburg, Russia
}

\author{
Olga E. Medvedeva \\ Faculty of Technological Management and Innovations \\ ITMO University \\ St. Petersburg, Russia \\ olmed@inbox.ru
}

\author{
Victor L. Vasilenok \\ Faculty of Technological Management and Innovations \\ ITMO University \\ St. Petersburg, Russia
}

\begin{abstract}
This article considers the main aspects of the application of innovative information technologies in the field of housing and communal services. The current state is considered and the main problems of informatization of housing and communal services are highlighted. Forecasted values and efficiency factor of ICT usage in the sphere of housing and communal services are calculated.
\end{abstract}

Keywords: housing and communal services, smart technologies, smart city, IT technologies, automated systems

\section{INTRODUCTION}

In recent years most constituent entities of the Russian Federation have either already created or are in the process of creating regional systems that collect and process information in the sphere of housing and communal services. In addition, large management and resource-supplying organizations, settlement centers, and in some cases homeowners' associations have introduced automated information systems which allow to work with data quickly and with high quality [1].

For example, Moscow United Energy Company OJSC, Rosvodokanal, Novokuznetsk Vodokanal, Mosenergo, Samaraenergo, Integrated Energy Systems Holding (IESHolding), Tyumen Energy Retail Company, United Energy Company are working on the SAP platform. In the republics of Tatarstan, Khakassia, Sakha (Yakutia), the Yamalo-Nenets Autonomous District, Astrakhan, Samara, Saratov, Ivanovo, Chelyabinsk, Vologda, Volgograd, and Tyumen Regions, the city of Novomoskovsk of the Tula Region they use the solution of the Bars Group company. However, the overwhelming majority of companies in the housing and utilities sector, as well as a number of regions of the country, work using individual IT solutions created by local developers. The current situation, apart from positive aspects formation of the market of IT solutions for the housing and utilities sector - has negative aspects.

The most common problem for all these systems is the isolation of the information stored and circulated in them. Based on their local needs, housing and utilities organizations create their own databases, collect, process and accumulate information using their own formats and IT solutions. Their information systems in many respects have local character, huge arrays of the data do not create uniform information space, there is no universal representation of the information.

In such conditions, the transfer of information from one database to another almost always requires additional preparation and processing which is carried out as a rule in manual mode. In other words, the industry has accumulated a huge amount of data that cannot be simply and quickly combined, processed and analyzed. Besides that, the acute problems in this area also remain:

- excessive deterioration of networks and structures

- increasing number of failures and accidents

- growing losses

- no transparency of the work system.

The vast majority of residents have a negative perception of what is happening to their homes and are actively fighting with management companies. Among the measures taken to improve the situation in the housing and utilities sector are the following:

- initiatives to modernize and upgrade engineering networks 
- collection and processing of telemetric information, as well as monitoring of indicators of the functioning of urban infrastructure;

- business accounting, etc.

In developed countries, the focus has now shifted from promoting products and services to creating value for customers by personalizing all services. Therefore, creating an organizational culture that encourages innovation and getting closer to consumers to find out what they really want is more important than ever in the public utilities sector. Thus, it is necessary to make innovations more systematic and cost effective [2].

According to Rosstat (Federal State Statistics Service), the penetration rate of ICT (Information and Communication Technologies) solutions in the housing and utilities sector is still low. For example, in 2018 only 65\% of resourcesupplying organizations used basic information technologies, including local networks, electronic document management systems and other similar solutions that caught up no more than $5 \%[3]$.

TABLE I. APPLICATION OF INFORMATION AND COMMUNICATION TECHNOLOGIES

\begin{tabular}{|c|c|c|c|c|c|c|c|}
\hline & \multicolumn{7}{|c|}{ Organizations used ICT, \% } \\
\hline & PC & $\begin{array}{c}\text { Ser } \\
\text { ver } \\
\boldsymbol{s}\end{array}$ & $\begin{array}{c}\text { Local } \\
\text { Area } \\
\text { Networ } \\
\text { ks }\end{array}$ & e-mail & $\begin{array}{c}\text { Global } \\
\text { informati } \\
\text { on } \\
\text { networks }\end{array}$ & $\begin{array}{c}\text { The } \\
\text { Intern } \\
\text { et }\end{array}$ & $\begin{array}{c}\text { ng } \\
\text { broadba } \\
\text { nd } \\
\text { access }\end{array}$ \\
\hline $\begin{array}{c}\text { Total } \\
\text { Reso } \\
\text { Irce } \\
\text { Provi } \\
\text { ders }\end{array}$ & 92.4 & 0.8 & 62.3 & 87.6 & 89.6 & 88.7 & 81.8 \\
\hline
\end{tabular}

According to statistics, $90 \%$ of resource-supplying companies use ICT such as personal computers, e-mail, global information networks (the Internet). Only 55\% of resourcesupplying organizations use servers in their activities.

TABLE II. ORGANIZATIONS THAT HAVE CREATED THEIR WEB-SITES (AS A PERCENTAGE OF THE TOTAL NUMBER OF SURVEYED ORGANIZATIONS OF THE RELEVANT TYPE OF ACTIVITY

\begin{tabular}{|c|l|l|l|l|l|l|}
\hline & $\mathbf{2 0 0 5}$ & $\mathbf{2 0 1 0}$ & $\mathbf{2 0 1 3}$ & $\mathbf{2 0 1 4}$ & $\mathbf{2 0 1 5}$ & $\mathbf{2 0 1 6}$ \\
\hline Total & 14.8 & 28.5 & 41.3 & 40.3 & 42.6 & 45.9 \\
\hline $\begin{array}{l}\text { Resource } \\
\text { Providers }\end{array}$ & 10.2 & 24 & 35.7 & 34.2 & 38.6 & 41.8 \\
\hline
\end{tabular}

The total number of resource-supplying organizations, which have their own WEB-site, has increased by 2016 compared to previous periods and reached $41.8 \%$ of the total number of resource-supplying companies. In addition, since 2005 there has been a growth in companies that use ICT in their operations. 
TABLE III. DISTRIBUTION OF ICT EXPENSES IN ORGANIZATIONS IN 2016 (IN PERCENT)

\begin{tabular}{|c|c|c|c|c|c|c|c|c|c|}
\hline & \multirow[b]{2}{*}{$\begin{array}{c}\text { Total } \\
\text { expenses for } \\
\text { information } \\
\quad \text { and } \\
\text { communicat } \\
\quad \text { ion } \\
\text { technologies }\end{array}$} & \multicolumn{8}{|c|}{ Including } \\
\hline & & $\begin{array}{c}\text { The cost of } \\
\text { the } \\
\text { purchase of } \\
\text { computing } \\
\text { and office } \\
\text { equipment }\end{array}$ & $\begin{array}{c}\text { The cost of } \\
\text { purchasing } \\
\text { communications } \\
\text { equipment }\end{array}$ & $\begin{array}{c}\text { Software } \\
\text { purchase } \\
\text { costs }\end{array}$ & $\begin{array}{c}\text { Costs of } \\
\text { communication } \\
\text { services }\end{array}$ & $\begin{array}{c}\text { Pay for } \\
\text { access to } \\
\text { the } \\
\text { Internet }\end{array}$ & $\begin{array}{c}\text { Employees } \\
\text { training } \\
\text { costs } \\
\text { associated } \\
\text { with the } \\
\text { development } \\
\text { and use of } \\
\text { ICT } \\
\end{array}$ & $\begin{array}{c}\text { Costs for third- } \\
\text { party services } \\
\text { and ICT } \\
\text { specialists } \\
\text { (except } \\
\text { communication } \\
\text { and training } \\
\text { services) } \\
\end{array}$ & $\begin{array}{c}\text { Other } \\
\text { costs }\end{array}$ \\
\hline $\begin{array}{c}\text { Total } \\
\text { organiza } \\
\text { tions } \\
\end{array}$ & 100 & 20 & 11.6 & 22.4 & 19.3 & 5.3 & 0.5 & 20.3 & 5.9 \\
\hline $\begin{array}{l}\text { Resourc } \\
\text { e } \\
\text { Provide } \\
\text { rs }\end{array}$ & 100 & 19.7 & 13.3 & 18.9 & 19.5 & 4.3 & 0.3 & 23.4 & 4.9 \\
\hline
\end{tabular}

a. Source: Federal State Statistics Service 2018

A large part of the costs of ICT resource-supplying organizations accounted for the payment of third-party services $(23.4 \%)$, the purchase of computing equipment $(19.7 \%)$, the payment for communication services (19.5\%), and the purchase of software $(18.9 \%)$. The smallest amount of funds is allocated for employee training $(0.3 \%)$, as well as to pay for access to the Internet (4.3\%).

Thus, based on statistical data, we can make a conclusion about the level of ICT usage by resource supplying companies in the course of their activities. Based on the data of 2016 less than half of resource-supplying organizations have a WEBsite. Servers for data storage use 55\% of organizations. Basically, companies in this industry use the simplest communication technologies, such as personal computers, email. All these show the underdevelopment of information and communication technologies.

Analysis of the cost of information and communication technologies has shown that the largest expense item is the cost of paying for services of third-party organizations and ICT specialists. Consequently, this indicates the lack of appropriate capabilities of personnel of resource-supplying organizations, their insufficient qualifications in the field of information and communication technologies. However, the share of expenditures on staff training is $0.3 \%$ of the total share of ICT expenditures. Thus, resource-supplying companies prefer to use the services of third-party organizations, rather than improving the skills of their own employees.

Utilities' IT leaders have the ability to use social networks as an environment to attract and retain customers for competitive resource-supplying companies, as a channel of interaction with consumers to stimulate customer participation in energy efficiency programs and as a new area of coordinated energy distribution based on crowd sourcing. Social networks for reporting disruptions are also becoming increasingly important and valuable for utilities and customers experiencing interruptions in work [4].

In a PwC survey conducted in May 2016 among British consumer utilities, 72 percent of respondents said they wouldn't have implemented Smart Home technology by 2020 . They also said they did not want to pay for it. But the rapid proliferation of smart home devices like Amazon Alexa and Google Home can change consumer attitudes faster than expected [5]. For example, the same survey showed that 81 percent of people with intelligent heating devices noticed a positive effect in the daily work of their home [6]. Problems faced by utility companies, should be resolved as soon as possible. And in this highly competitive and sensitive market with many fluctuations in wider ecosystems, lead time and awareness of the benefits of "new technologies" is the key to survival.

Currently, IT companies offer solutions for such new challenges as: cloud computing (Cloud) and cloud analytics, explosive data growth (Big Data), the introduction of smart metering and smart networks (Smart Grid), the need to create new services and interaction channels that provide two-way communication with consumers, tracking critical parameters of core business, faster growth of costs before the growth of tariffs, ensuring the reliability of the collected consumption data, ensuring the availability of acting with network companies and local authorities [7]. The main technological changes that play a decisive role in the field of public services are:

- Internet of Things (IoT). Obviously, IoT (smart meters, smart grids, power management, etc.) is of great importance in the field of utilities. According to Gartner's leading analyst, 299 million IoT units have been installed on the utilities market, making it the second after production; in international practice, successful examples of IoT implementation in the European Union countries, South Korea, China and India are known;

- Big Data. Along with the emergence of "smart devices", as well as for many other reasons, including the decisive role of data in an industry where data is of great importance from all points of view, dealing with the amount of data generated and especially turning all this data into competitive. Increased efficiency and 
customer benefits are a key priority for utilities. Content analytics plays a key role here.

According to UN forecasts by 2030 the share of the urban population in the total population of the planet will be $80 \%$. At the same time, a number of megacities of the world in developing countries are experiencing a particularly serious "growth crisis" today - they are Buenos Aires, Johannesburg, Mumbai, Moscow, etc. [8]

For example, in China the implementation of a program unprecedented on the planet for the resettlement of a quarter of a billion rural residents to cities has begun [9]. Together with the population, communication lines are growing, infrastructure is becoming complicated, the scale of problems is growing. In Russia, an additional risk factor is the deterioration of urban communications: only according to official data, in Russia 78-80 percent of fixed assets of housing and public utilities require capital repairs or replacement.

Such problems as increasing the manageability of the city itself as an organism, reducing the cost of operating the urban infrastructure, speeding up the response to critical damage and threats, optimizing the use of resources, etc. and cause the need to create highly intelligent systems for collecting, processing and analyzing data. As a rule, these systems themselves today are most often referred to as "smart city", or "smart city".

As part of digitalization a number of national projects are being implemented in Russia. One of them is "Digital Economy", within the framework of this national project the Ministry of Construction and Housing and Public Utilities has two subprojects [10]. The first one is "Smart City", the second is "Digital Construction".

The smart city is the widest field of information technologies application and engineering innovations. A modern city is a colossal integrated environment in which everyone should be comfortable. In the project "Smart City", the Ministry of Construction of the Russian Federation implements measures related to understanding what set of tools is required for it, what technological solutions will be needed. We can say that today the ministry is in the mode of working out the strategy, where to go and what to do. There are relevant developments in other countries, but it is necessary to understand how to tie them to Russian conditions.

Construction companies in such countries as Germany, the USA, Canada, Holland, at the construction stage, adopt smart technologies for housing and public utilities, thereby increasing the class of housing being built. In such a situation one of the incentives for buying an apartment in a particular house is the availability of digital services [11]

For example, a person buying an apartment in a house where video surveillance and smart intercom are already installed, together with square meters, receives in his apartment a ready-to-use smart home system, paved communications for the Internet, television and telephone, smart meters for water, electricity and gas. The buyer no longer needs to spend time installing systems and laying networks across the entire apartment, no need to think about how to do this. It simply downloads the app and controls all devices from the smartphone. In addition to comfort and safety, digital technologies help save on monthly utility bills. And this may also affect the decision to buy an apartment in a particular house. As for the availability of digital solutions outside large cities, the experience and technical capabilities of the company implementing smart technologies are of great importance. An example of innovative digital technology is LoRa access and data transfer technology. It allows implementing digital solutions for developers, management companies and utilities in any city.

The Russian model in the housing and utilities sector is the concentration of all types of services in one company management, repair and maintenance of a house. The effectiveness of such a model is not great and, as practice shows, has a negative connotation, the quality of services falls from year to year. Therefore, in the conditions of the modern market the development of this sector of economy requires a clear diversification of services [12]. Every Russian has repeatedly asked himself the question of the formation of invoices for housing and communal services. Also, many management companies deliberately and unreasonably overestimate prices for their services.

France and Finland are exemplary from this point of view. For these states information technology is an integral part of public services. Automation allows you to quickly and efficiently perform operations, interact with representatives of public utilities remotely. It is convenient, economical and allows you to spend the vacated time much more beneficially. Smart Grid - the technology of "smart" power supply networks, a fundamentally new approach used in advanced countries to improve the reliability and cost-effectiveness of the entire energy system, maintaining the balance of production and energy consumption.

In Germany, the introduction of integrated solutions for the rational use of water, gas, heat and electricity has been going on for a long time [13]. The equipment of apartment buildings is carried out by the use of modern smart devices for measuring the consumption of resources connected to a software product for tracking their accounting in real time [14].

In the United Kingdom and the United States, large-scale programs have been implemented for the introduction of smart meters for remote control of household energy consumption.

In Manhattan (New York, the USA), when introducing a system of smart electricity metering based on the SAP HANA solution, each house in the district was equipped with a smart meter that sends data to the metering center every five minutes. At the same time, the municipality, depending on the level of electricity consumption, can allocate zones of varying intensity of consumption. This decision saves Manhattan up to 80 percent of power consumption.

\section{RESULTS}

Predictive assessment of the introduction of information technology. 
TABLE IV. ANALYTICAL INDICATORS OF THE GROWTH DYNAMICS OF ICT IMPLEMENTATION BY RESOURCE-SUPPLYING ORGANIZATIONS (\%)

\begin{tabular}{|c|c|c|c|c|c|c|c|c|c|c|}
\hline $\begin{array}{l}\text { Value } \\
\text { for the } \\
\text { period }\end{array}$ & $\begin{array}{c}\text { Base } \\
\text { absolute } \\
\text { increment } \\
\text { (differenc } \\
\text { e of } \\
\text { current } \\
\text { and base } \\
\text { values) }\end{array}$ & $\begin{array}{c}\text { Chain } \\
\text { absolute } \\
\text { gain (the } \\
\text { difference } \\
\text { between } \\
\text { the } \\
\text { current } \\
\text { and } \\
\text { previous } \\
\text { values) } \\
\end{array}$ & $\begin{array}{c}\text { Baseline } \\
\text { growth } \\
\text { rate (ratio } \\
\text { of current } \\
\text { and } \\
\text { baseline } \\
\text { values) }\end{array}$ & $\begin{array}{c}\text { Chain } \\
\text { growth rate } \\
\text { (the ratio of } \\
\text { current and } \\
\text { previous } \\
\text { values) }\end{array}$ & $\begin{array}{c}\text { Basic } \\
\text { growth } \\
\text { rate (ratio } \\
\text { of } \\
\text { absolute } \\
\text { basic } \\
\text { growth } \\
\text { and basic } \\
\text { value) } \\
\end{array}$ & $\begin{array}{c}\text { Chain growth } \\
\text { rate (the ratio } \\
\text { of the absolute } \\
\text { chain growth } \\
\text { and the } \\
\text { previous } \\
\text { value) }\end{array}$ & $\begin{array}{c}\text { Absolut } \\
e \text { value } \\
\text { of } 1 \% \\
\text { increas } \\
e\end{array}$ & $\begin{array}{c}\text { Absolute } \\
\text { acceleration (the } \\
\text { difference } \\
\text { between the } \\
\text { absolute } \\
\text { increase of the } \\
\text { period and the } \\
\text { absolute } \\
\text { increase of the } \\
\text { previous period) }\end{array}$ & $\begin{array}{c}\text { Relative } \\
\text { acceleration } \\
\text { (the ratio of } \\
\text { the chain } \\
\text { increase for } \\
\text { the period and } \\
\text { the chain } \\
\text { increase for } \\
\text { the previous } \\
\text { period) }\end{array}$ & $\begin{array}{c}\text { Rate of } \\
\text { increase } \\
\text { (the ratio of } \\
\text { the chain } \\
\text { increase } \\
\text { and the base } \\
\text { value) } \\
\end{array}$ \\
\hline \multicolumn{11}{|l|}{10.20} \\
\hline 24.00 & 13.80 & 13.80 & 2.35 & 2.35 & 1.35 & 1.35 & 0.10 & & & 1.35 \\
\hline 35.70 & 25.50 & 11.70 & 3.50 & 1.49 & 2.50 & 0.49 & 0.24 & -2.10 & 0.36 & 1.15 \\
\hline 34.20 & 24.00 & -1.50 & 3.35 & 0.96 & 2.35 & -0.04 & 0.36 & -13.20 & -0.09 & -0.15 \\
\hline 38.60 & 28.40 & 4.40 & 3.78 & 1.13 & 2.78 & 0.13 & 0.34 & 5.90 & -3.06 & 0.43 \\
\hline 41.80 & 31.60 & 3.20 & 4.10 & 1.08 & 3.10 & 0.08 & 0.37 & -1.20 & 0.64 & 0.31 \\
\hline
\end{tabular}

Based on the statistical data presented above, it is possible to identify the dynamics and growth rate of ICT in resourcesupplying companies. Using the information provided in Table 2 , the necessary indicators were calculated.

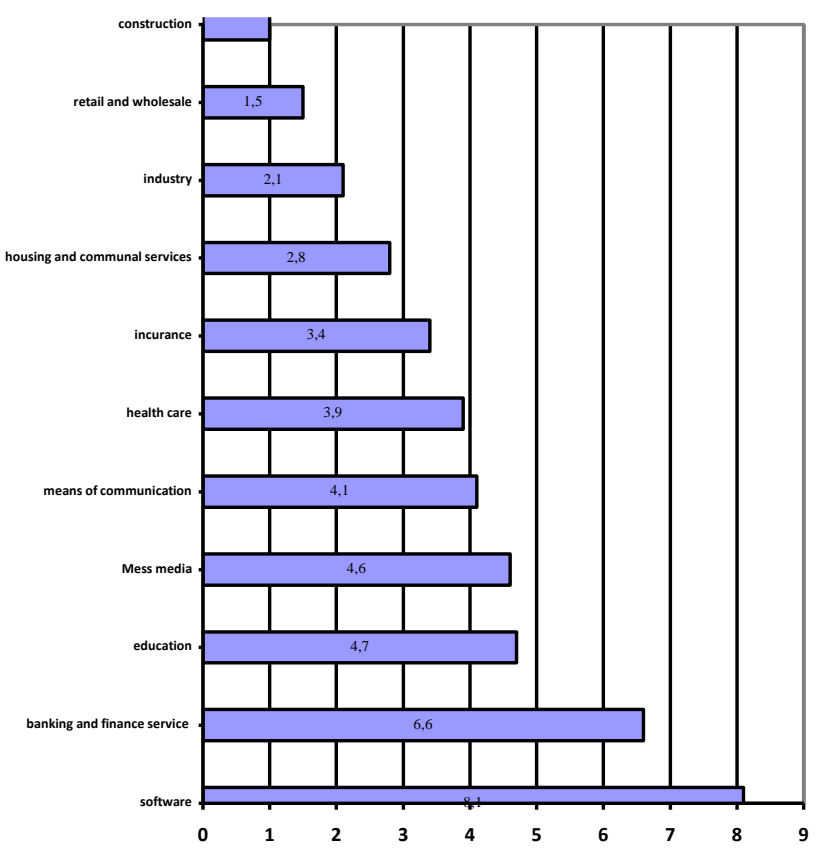

Fig. 1. Expenses as a \% of the company's revenue in the ICT areas of activity for 2017 (in the world)

From Diagram 1 it can be seen that the percentage of their revenues that companies send to the introduction of ICT is quite small. Although companies from the sphere of Internet services and banking (financial) services are undoubtedly the leaders in investing revenues in the informatization of their processes $(8.1 \%$ and $6.6 \%)$. But the housing sector remains an outsider, only $2.8 \%$ of the income received is sent to ICT. If we speak in terms of growth potential, then this housing and utilities sector has a lot of potential.
Thus, the average growth rate of resource-supply organizations using ICT was 1.32. Consequently, there is an opportunity to make predicted values for the nearest periods.

TABLE V. FORECASTING THE NUMBER OF RESOURCE SUPPLY ORGANIZATIONS USING ICT

\begin{tabular}{|l|l|}
\hline Year & $\begin{array}{c}\text { The number of companies (as a percentage of the } \\
\text { total number of resource-supplying companies) }\end{array}$ \\
\hline 2017 & 55.42 \\
\hline 2018 & 73.48 \\
\hline 2019 & 97.43 \\
\hline
\end{tabular}

Thus, the growth rate of resource-supplying organizations using information and communication technologies was revealed. Based on the growth rate (1.32), forecasts were made for the coming periods. The analysis shows that since the growth of ICT usage (since 2005, the average number of organizations applying ICT has increased by 30\%), by 2020 it is expected to be $97 \%$ of resource-supplying companies that will be using information and communication technologies in their activities.

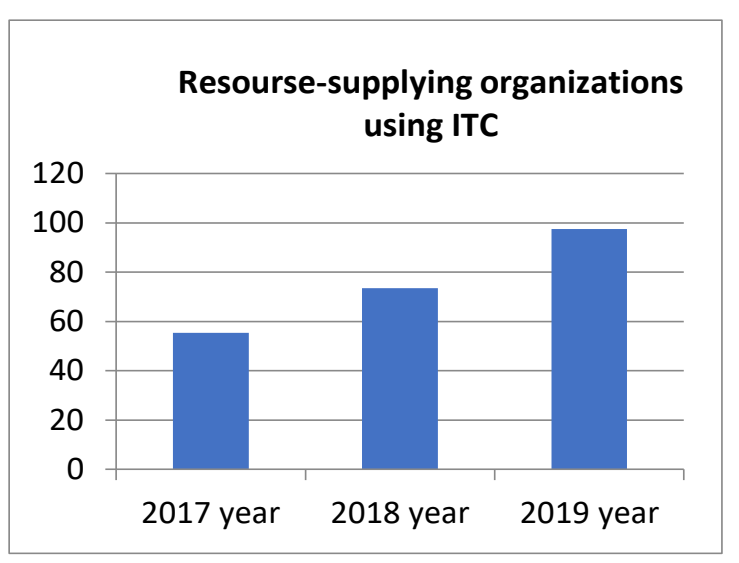

Fig. 2. Resourse-supplying organizations using ITC 
According to Rosstat, at the moment the penetration rate of

A common approach to determine the effectiveness of ICT implementation is the ratio of profits and total costs of an enterprise. The problem is that the influence of information technologies on the profitability of an enterprise is mediated and manifested in improving the business processes of an enterprise, increasing the efficiency of obtaining analytical data, making management decisions, etc. Consequently, the value of the index of effectiveness will not be able to provide accurate information about the rationality of a specific information technology implementation to some extent. This is due to the problems of determining the results of automation, since it is not enough to calculate efficiency as the difference between the resources expended and the savings obtained in the present context. The effects become much more complex and should be evaluated in terms of the strategic goals of the entire development of the enterprise. In the Russian business environment there is currently no unified approach to assessing the effectiveness of introducing information technologies.

Industrial enterprises apply or adapt guidelines for assessing the effectiveness of investment projects approved by government agencies. The analysis quite often takes an informal character for IT managers who rely on their own experience or on the estimates of "experts" [15].

Obviously, the majority of publications in the field of ICT describe economic growth and productivity, concentrate on investments in ICT in general, and there is little evidence on the impact of ICT use on economic growth and productivity.

In our study to determine the effectiveness of ICT implementation by Russian companies in the housing and utilities sector we took as a basis Rosstat data and indicators to characterize the software usage by management companies, including system-wide, special and applied, as well as indicators of the level of use of technical support, defining a set of technical means for equipping a specialist's workplace (computers of any models; devices for collecting, accumulating information as well as its processing, transmission and organization of output; data transfer devices; office equipment, etc.). We proceeded to calculating the weights using the Fishburn scale to determine the level of ICT efficiency achieved. The results were disappointing: only 30 per cent of all companies use ICT across the board, with an average overall ICT efficiency of 0.35 , indicating a low level of economic efficiency.

\section{CONCLUSIONS}

Thus, based on our research, we can draw the following conclusions. Housing and communal services is one of the key sectors of the Russian economy. Despite the fact that in recent years this area has undergone some positive changes many global problems still remain unresolved. The most serious problems accompanying the processes of digital transformation of housing and public utilities include the formation of effective mechanisms for financing the installation of residential utility meters in apartments and households of Russians without which digitalization of the industry is impossible.
ICT solutions in housing and utilities is still low. For example, only $65 \%$ of resource-supplying organizations in 2018 used basic information technologies, including local networks, electronic document management systems and other similar solutions - no more than 5\%; about $90 \%$ of resource-supplying companies use ICT such as personal computers, e-mail, global information networks (the Internet). Only 55\% of resourcesupplying organizations use servers in their activities.

Based on the data of 2017 we can conclude about the level of use of ICT by resource-supplying companies in the course of their activities where less than half of the resourcesupplying organizations have a WEB-site. Servers for data storage are used by $55 \%$ of the organizations. Basically, companies in this industry use the simplest communication technologies, such as personal computers, e-mail. All this shows of the underdevelopment of information and communication technologies.

The main technological changes that play a decisive role in the field of public services are:

- Internet of Things (IoT) (smart meters, smart grids, power management, etc.);

\section{- Big Data.}

The analysis conducted in the work showed that by 2020 it is expected to increase to $97 \%$ of resource supplying companies that will use information and communication technologies in their activities. And the future success of business in the sphere of housing and communal services will consist in transparency and disclosure.

\section{References}

[1] R.V. Fattakhov, The effectiveness of regional authorities in the housing and utilities sector: a toolkit for analysis and evaluation: a monograph. Financial University under the Government of the Russian Federation, 147 p., 2012.

[2] A.M. Lavrova, The effectiveness of budget expenditures at the regional level. M.: All the World Publishing House, 76 p., 2003.

[3] On the evaluation of the effectiveness of the executive authorities of the Russian Federation: Presidential Decree of 11.14.2017, no. 548, Meeting of the legislation, no. 47, art. 6963, 2017.

[4] Y. Kolyhaeva, "The Development of Information Technologies in the Sphere of Housing Service and Utilities as a Factor of National Life Quality Increase", Procedia - Social and Behavioral Sciences, vol. 166, p. 557-561, 2015.

[5] Foreign experience of housing and communal services and the possibility of its use in Russia, 2017 [Electronic resource]. Available at: https://www.gkh.ru/article/102164-zarubejnyy-opyt-jkh.

[6] M.A. Eskindarova and S.N. Silvestrova, "Russian Economy in 2010 2012: trends, analysis, forecast: analytical report", Financial University under the Government of the Russian Federation, Institute for Financial and Economic Research, Foundation for Assistance in Implementing Scientific Developments SONAR, 114 p., 2012.

[7] R.V. Fattakhov and M.M. Nizamutdinov, Management Efficiency of the Housing and Public Utilities Sphere in the Regions: An Analysis of the Situation and Approaches to Assessment, Strategic planning and development of enterprises: Sat. scientific tr., CEMI RAS, pp. 123-127, 2014.

[8] J. Critchlow and J. Glickman, Digital Strategy for Utilities, 2018 [Electronic source]. Available at: https://www.bain.com/insights/digital-strategy-for-utilities/. 
[13] Management of housing and communal services in Germany, 2014 [Electronic resource]. Available at: http://all-about-g

[9] A. Flores, Transformation in utilities, 2017 [Electronic source]. Available https://www.sapientrazorfish.com/articles/2016/transformation-inutilities.

[10] A.G. Ataeva and G.R. Zinnurov, "Some aspects of the provision and financing of municipal services to meet the basic needs of economic agents of the municipality", Audit and financial analysis, no. 2, pp. 274-278, 2012.

[11] How is housing and communal services in other countries, 2018 [Electronic resource]. Available at: http://foxtime.ru/article/kakustroeno-zhkh-v-drugih-stranah.

[12] A.A. Neshchadin and R.V. Fattakhov, "Priorities of state policy in the field of regional development of the Russian Federation", Society and Economics, no. 1-2, pp. 108-123, 2013.
[14] J. Critchlow and Ja. Glickman, J. Digital Strategy for Utilities, 2018 [Electronic source]. Available at: https://www.bain.com/insights/digital-strategy-for-utilities/.

[15] Housing and communal complex of Germany Practice, Innovations, Electron. Dan., Sorokina Publishing House [Electronic resource]. Available at: http://www.ids55.ru/ks/articles/48-2013-03-15-03-5006/1337-s----.html.

[16] Reforming housing and communal services in Russia, 2015 [Electronic resource]. Available http://www.worldbank.org/en/news/feature/2015/04/28/reformingrussias-housing-and-communal-services-sector. 